\title{
Sikó BeÁtA*
}

\section{A (NYUGATI) VALLÁSOK REPREZENTÁCIÓJA 19. SZÁZADI ERDÉLYI (UNITÁRIUS) UTAZÓK ÍRÁSAIBAN}

\author{
Kulcsszavak: utazó, unitárius, 19. század, vallási sokszínüség és sokféleség, Voltaire, \\ tolerancia, lelkiismereti szabadság
}

A 18. századi utazók és útleírók voltak azon első európaiak, akik az utazást és folyamatát már tapasztalatként és élményként közvetítették, illetve eszmeként és ideológiaként is reprezentálták vagy kritizálták. Például az angliai kvékerekkel való találkozás tapasztalatából merítve Voltaire az Ancien Régime, a régi rendszerrel szembeni kritikáját fogalmazta meg Filozófiai levelek (Lettres philosophiques) címú írásában, miközben szembeállította azt a tolerancia és észszerúség eszméit hirdető Angliával. ${ }^{1}$ Érdekes narrációs megoldáshoz folyamodva - az idős kvéker szemszögéből láttatva - a francia etikettet, a túlontúl mesterkélt és szertartásszerú viselkedésformákat kritizálja az Elsô levében:

„Valld csak be - mondta -, alig tudod elfojtani nevetésedet, amikor udvariaskodásodra le se vettem kalapomat és tegezve válaszoltam, pedig eléggé múveltnek látszol abhoz, hogy tudd: Krisztus idejében egyetlen nép sem választotta ketté ily nevetségesen a tegezést meg a magázást. [..]. A hazugság és hizelgés e hitvány gyakorlata ellen védekezve mi a királyokat és a foltozóvargákat egyaránt tegezzük, nem köszönünk senkinek". ${ }^{2}$

A francia utazók már a 17. század vége óta nagy érdeklődést mutattak a kvékerek, a kvékerizmus iránt, és fôként pozitív fényben láttatták e vallás-felekezeti mozgalmat. ${ }^{3}$ Múvében maga Voltaire is szintén elismerôleg nyilatkozik róluk (például dicséri a kvékerek esetében a keresztség, az úrvacsora, illetve a klérus hiányát), de nem csupán a kvékerekkel foglalkozik, mivel elemzésének tárgya az angolok vallásos élete lesz. Voltaire mint az Ancien Régime világából érkező deista gondolkodó a 18. században, a lelkiismereti szabadság és tolerancia esz-

* Sıкó Beáta (1988): jelenleg doktorandus, Babeş-Bolyai Tudományegyetem, Hungarológiai Tanulmányok Doktori Iskola (2. év). 2010-ben a BBTE Bölcsészettudományi Karán diplomázott magyar-angol szakon, majd ugyanitt 2012-ben mesterfokozatú diplomát szerzett magyar nyelvészeti és irodalmi tanulmányok szakon. Főbb kutatási területe a 19. századi utazási irodalom, elsősorban erdélyi utazók útleírásaival, utazástörténeteivel foglalkozik.

1 Jan Gorak: Travel as Art and Travel as Act in the Troubled Twentieth Century. 'The Traveller's Eye: Narrating Dis/Location in $20^{\text {th }}$ Century Travel Literature` konferencián elhangzott előadás alapján.

2 Voltaire Válogatott filozófiai írások. Gond., előszó Ludassy Mária, ford. Kis János, RÉz Pál. Akadémiai, Bp., 1991 (Filozófiai Írók Tára 37). 39.

3 Uo. 36. 
méjének a megvalósulását látja Angliában: „Anglia a szekták országa. Egy angol, mint szabad ember, azon az úton igyekszik az égbe, amelyen kedve tartja” ${ }^{4}$ Ám a különböző vallásokat és követőiket nem csak kuriózumként, érdekességből mutatja be, hanem górcső alá véve kritikusan szemléli azokat, mivel rámutat e szervezett vallási formák manipulatív jellegére és híveik fanatizmusára:

„Íme, hogyan élt vissza ez a szent ember, igencsak körmönfontan, a Szentírás három vagy négy passzusával, amely kedvezni látszott szektájának, de, ha jóbiszemúen is, megfeledkezett száz más száz passzusról, amely összezúzta volna érveit. Óvakodtam tiltakozni, egy rajongót úgysem lehet meggyózni".

Voltaire után csaknem 100 évvel, a deista gondolkodóhoz hasonlóan a felvilágosodás filozófiáján nevelkedett Bölöni Farkas Sándor utazóként is úgy tesz látogatást Angliában, illetve az Amerikai Egyesült Államokban, hogy azáltal hogy bemutatja útikönyvében a nyugat különböző vívmányait (politikai, társadalmi, technikai vívmányok) prózájában impliciten kifejezésre juttatja a régi rendszer, a feudalizmus rendszerében és eszmevilágában megrekedt hazájával szembeni kritikáját. Így az Utazás Észak-Amerikában címú útikönyve akkoriban sokkal több volt, mint egy úti beszámoló, a Schoenman-fordítópáros szerint egy politikai kiáltványként is értelmezhető, amelyben a politikai és társadalmi átalakulást, a (polgári) demokráciához vezető átalakulást szorgalmazta. ${ }^{6}$ A gondosan megszerkesztett útikönyvben az olvasóközönség figyelmét a polgári demokrácia különböző vívmányaira irányította, különös figyelmet szentelve az amerikai sokrétű vallásos élet bemutatására, illetve a vallások jogi helyzetének a taglalására. Ebből kifolyólag az Amerikai Egyesült Államokat úgy tárta az olvasó elé, mint a vallásos szabadság és tolerancia fellegvárát, ahol minden felekezet békében megfér egymás mellett, és ahol az alkotmány által biztosított a lelkiismeret, illetve a gondolkodás szabadsága minden egyén számára. Amint az Államok felekezeti statisztikáját közli, ugyanezt a gondolatot hangsúlyozza:

„Itt nincs státusvallás, hogy minden névvel nevezendő felekezetbeliek egyforma jussal birnak, hogy már több van ötven vallásnál [...] S végre hogy minden polgár szabadosan egyik vallásról a másra léphet, soly vallást alkothat, milyent meggyózódése kíván.”

Míg az Amerikai Egyesült Államok számára a vallási türelmesség megtestesülése, addig Európa ennek ellenpólusaként jelenik meg. Európa viszonyítási pontként úgy reprezentálódik, mint a vallási türelmetlenség és bigottság kontinense:

4 Uo. 49.

5 Uo. 38.

6 Alexander Bölöni Farkas Journey in North America. Translated, ed. Theodore and Helen Benedek Schoenman. Philadelphia, American Philosophical Society, 1977. 14-15. 
„... ók félszázad ólta az Európában annyi századokon által milliók vérével megírt dogmatikai igazságok truccára éppen az ellenkezót akarják bebizonyitani. Ily bebizonyitás a többek közt az itteni egymástól különbözó s egészen függetlenül álló felekezetek nagy száma”. ${ }^{7}$

Tanulmányom következő részében Bölöni Farkas útikönyvének és útinaplójának azon szöveghelyeit rendszerezem és értelmezem, amelyek a (nyugati) vallásokkal, felekezetekkel kapcsolatos leírások, összefoglalók, illetve rövidebb narratívák. Az amerikai élményeket rögzítő útikönyvet három olyan (protestáns) vallási irányzat, vallási közösség reprezentációja szervezi, amelyek nem pusztán kuriózumként vannak megjelenítve, hanem eszmei mondanivaló is kapcsolódik ezekhez. Az utazó-útleíró közvetlen, ám külső szemtanúként jeleníti meg a shakerek, metodisták és kvékerek Istenhez való folyamodásának különböző módjait, amelyek látványa elmélkedésre ösztönzi. Különböző szempontok szerint szerveződnek ezen „élménybeszámolók”, és az alábbi táblázat egy-egy útikönyvbeli idézettel szemlélteti ezen szervező elemeket. ${ }^{8}$

\begin{tabular}{|c|c|c|c|}
\hline & SHAKEREK & METODISTÁK & KVÉKEREK \\
\hline $\begin{array}{l}\text { 1. hit/ } \\
\text { hitvallás } \\
\text { fó elve } \\
\text { - dogma- } \\
\text { tikai alap }\end{array}$ & $\begin{array}{l}\text { "A Bibliában több helyen fordul elé, } \\
\text { hogy a zsidóknál tánccal is imádták } \\
\text { Istent, p.o., hogy Dávid király is } \\
\text { táncolt a frigyláda körül. Salamon } \\
\text { prófétánál is e mondatik: Minden- } \\
\text { nek ideje van!' -s ott a több foglala- } \\
\text { tosságok közt a tánc is emlittetik." } \\
\text { (119) }\end{array}$ & $\begin{array}{l}\text { "A methodisták dogmá- } \\
\text { joknak ezen különes ágát } \\
\text { a szentirás azon helyei- } \\
\text { ból veszik, hol ezek mon- } \\
\text { datnak: Emeljétek fel ke- } \\
\text { zeiteket az Úrhoz, zör- } \\
\text { gessetek s megadatik. } \\
\text { - Kiáltsatok az Uristen- } \\
\text { hez. - Ordítsatok az Úr- } \\
\text { nak hegyén." (124) }\end{array}$ & - \\
\hline $\begin{array}{l}2 . \\
\text { templom/ } \\
\text { gyüleke- } \\
\text { zeti hely }\end{array}$ & $\begin{array}{l}\text { „Templomjok belsöje egyszerü, nagy } \\
\text { ablakokkal hasonlít egy szép terem- } \\
\text { hez. Semmi cifraság benne, az iste- } \\
\text { ni tiszteletnek semmi attributuma, } \\
\text { mely vallásos gyülekezet helyét } \\
\text { gyanittatná." (120) }\end{array}$ & $\begin{array}{l}\text { „A methodisták felekeze- } \\
\text { te minden esztendön ösz- } \\
\text { szel és tavasszal nyolc } \\
\text { napig mezei gyüléseket } \\
\text { (camp-meetings) szokott } \\
\text { tartani. ... A sátorok } \\
\text { messze terjedö félkörben } \\
\text { voltak felvonva, söztök } \\
\text { sikátorok. ... A félkör kö- } \\
\text { zepén egy nagy, magas } \\
\text { deszkaállás nyült fel ka- } \\
\text { rozattal, mely a prédiká- } \\
\text { lószék.” (123) }\end{array}$ & $\begin{array}{l}\text { „Midôn belépett az idegen, nem } \\
\text { tudta, ba valóban templom } \\
\text { van-e. A kopac falakon semmi } \\
\text { attributum, nincs katedra, nincs } \\
\text { orgona, sem pap; senkinek nincs } \\
\text { könyv kezében, s a vallásnak so- } \\
\text { hult semmi külsó jele." (300) }\end{array}$ \\
\hline
\end{tabular}

7 Bölöni Farkas Sándor Utazás Észak-Amerikában. Szerk. Benkő Samu. Irodalmi, Buk., 1966. 218.

8 Az idézett oldalszám zárójelben szerepel. (BöLöNi FAR Kas S.: i. m. 1966). 


\begin{tabular}{|c|c|c|c|}
\hline 3. öltözék & $\begin{array}{l}\text { „A férfiak öltözete egyformán pa- } \\
\text { pucs és fejér strimfli, pantallon, sze- } \\
\text { derjes, hosszú szabatú mellény, kes- } \\
\text { keny, fejér nyakravaló... Az asszo- } \\
\text { nyoké hónyalj alatt szoritott, kávé- } \\
\text { szin vagy fekete felsö köntös, fejér } \\
\text { keszkenövel boritott mell.”(120) }\end{array}$ & - & $\begin{array}{l}\text { „A férfiak fekete öltözetben, szé- } \\
\text { les karimájú kalapjokat szem- } \\
\text { ökre vonva, földre szegzett an- } \\
\text { dalgó tekintettel. ... az asszo- } \\
\text { nyok sötétszin köntösben, sima, } \\
\text { mély kalappal, elboritott mely- } \\
\text { lyel, mozdulatlan elmerülés- } \\
\text { ben." (300) }\end{array}$ \\
\hline $\begin{array}{l}4 . \\
\text { életmód }\end{array}$ & $\begin{array}{l}\text { "A shakerek fó elve: a vagyon kö- } \\
\text { zössége. Senkinek nincs elkülö- } \\
\text { nözött vagyona, az mind a közön- } \\
\text { ségé. Munkájok gyümölcse a köz- } \\
\text { tárba tétetik, honnan van élelmök } \\
\text { és rubázatjok. A nötelenség megki- } \\
\text { vántató feltétel. A felekezet minden } \\
\text { tagjai, férfiak és asszonyok, egyen- } \\
\text { loók minden jussokban." (119) }\end{array}$ & $\begin{array}{l}\text { "A methodisták felekeze- } \\
\text { te számos, de csak a nép } \\
\text { miveletenebb osztályából } \\
\text { állanak követöi." (124) }\end{array}$ & $\begin{array}{l}\text { „Ók becsületességökröl a közvé- } \\
\text { lekedésben legelöl állanak. A } \\
\text { quaker szava szent, az egyezés- } \\
\text { ben contractus, a társalkodásban } \\
\text { a sziv igaz értelme. A jótételben, } \\
\text { közjó elémozditásában és va- } \\
\text { gyoni áldozattételekben a } \\
\text { quakerek elsök. ... Köztük egy- } \\
\text { formaság van, rangot, konven- } \\
\text { ció szabályait nem ismerik, a } \\
\text { rendszerezö teorizálásnak nem } \\
\text { pártfogói. Nagy része tanult és } \\
\text { mivelt ember."(301) }\end{array}$ \\
\hline $\begin{array}{l}5 . \\
\text { istentisz- } \\
\text { telet } \\
\text { jellege } \\
\text { - menete }\end{array}$ & $\begin{array}{l}\text { „Isteni tiszteletjeknek egy része tán- } \\
\text { colásból áll ... Az ének közben } \\
\text { szüntelen libegett két kezök, mintha } \\
\text { repülni készülnének. Végezvén az } \\
\text { éneket, megint mély csendesség lett, s } \\
\text { nehány perc múlva egy öreg shaker } \\
\text { valamely imádság formát mondott. } \\
\text { Az imádság végzódvén, egy másik } \\
\text { felszólalt: munkálkodjunk, atyám- } \\
\text { fiai! Az énekre újra libegtek a kezek, } \\
\text { s férfi és asszony táncfigurákot kez- } \\
\text { dettek csinálni." (121) }\end{array}$ & $\begin{array}{l}\text { „Beljebb a sátorban asz- } \\
\text { szonyok és leányok tér- } \\
\text { deltek a szalmában, s } \\
\text { ezek is különbözó ránga- } \\
\text { tódzások közt ismételték } \\
\text { e szavakot. Az egyik ke- } \\
\text { servesen zokogott; a más } \\
\text { eltakarta arcáját, megint } \\
\text { a más ájuldozott, s szom- } \\
\text { szédja ölébe döledezve } \\
\text { merengette szemeit az ég } \\
\text { felé." (123) }\end{array}$ & $\begin{array}{l}\text { "Mély csendesség uralkodott. ... } \\
\text { És e helyzetet semmi vallásos ce- } \\
\text { remónia meg nem szakasztja, } \\
\text { kivérvén azon ritka esetet, ha } \\
\text { valaki a Szentlélek erejét mun- } \\
\text { kálva érezvén magába, szent } \\
\text { sugallatait a közönséghez inté- } \\
\text { zett beszédében önti ki, melynek } \\
\text { ballgatására mindenik feláll, s } \\
\text { végezetével elébbi helyzetébe } \\
\text { merül vissza." (301) }\end{array}$ \\
\hline
\end{tabular}

Amint fenti táblázatban is látható, a dogmatikai alap ismertetése után az utazó-útleíró különös figyelmet szentel e három vallási felekezet gyülekezeti helyeinek a szemléletes és aprólékos leírására, illetve mivel az egy felekezethez tartozókat viselet szerint uniformitás jellemzi, külön ír öltözködésükről is. Emellett részletesen kifejti életmódjukat, bemutatja társadalmi szervezési formáikat és berendezkedéseiket. A nagyobb hangsúlyt a különböző istentiszteletek menetének a részletezésére fekteti, és kiemeli a ceremóniák legfóbb jellegzetességeit. Ezen istentiszteletek különböző reakciót váltanak ki a szemlélő utazóból: míg a kvékerek néma istentiszteletét figyelve már Londonban megihletődik, lenyűgözi minden tekintetben e vallás némasága, valamint követői életmódjának feddhetetlensége, teljesen azonosul velük, addig a shakerek és metodisták különös ceremóniáját figyelve szánakozás fogja el. ${ }^{9}$

9 A fentebbi táblázatot, illetve e kutatás részeredményeit bemutattam a II. Interdiszciplináris Dokorandusz Konferencián (Pécs, 2013) A vallási sokféleség megjelenése Bölöni Farkas Sándor útinap- 
Mivel az amerikai útikönyvből elsősorban koncepcionális okok, másodsorban pedig terjedelmi okok miatt kimaradtak a nyugat-európai utazás élményei, így célszerünek vélem annak a megvizsgálását is, hogy milyen a vallások reprezentációja az útinaplóban. Az útinapló franciaországi részében kiderül, hogy az utazó - saját szóhasználatával élve - két új vallásbeli sectára figyel fel, amelyek megjelenését és intézményesülését az 1830-as év júliusi eseményei - revolúció -, illetve az új francia alkotmány - charta - tették lehetővé. Az egyik a saintsimonizmus, a másik pedig a réligion catholique française. ${ }^{10}$ A saint-simonizmus valójában egy filozófiai iskola, melynek tanai Saint-Simon francia gondolkodó utópista szocialista elméletére épülnek (kizsákmányolás nélküli ipari társadalom), de halála után 1832-ben teljes kollektivizmust hirdető szektává alakul át. ${ }^{11}$ Erdély konfesszionálisan heterogén, ám a nyugathoz képest mégis homogénebb világából érkező utazó figyelme az újonnan alakult és szerveződött vallásokra irányul, azon szakadár vallásokéra, amelyek a közelmúltban nyertek legitimitást az által, hogy az új francia alkotmány minden egyén számára biztosítja a szabad vallásgyakorlás lehetőségét.

Az útinapló angliai részét olvasva kiderül, hogy az utazó-útleíró érdeklődésének kiemelt tárgya az anglikán államvallás mellett a kvékerizmus és a kvékerek gyülekezete. Az útinapló június 27-ei bejegyzésében önmagát azon szemlélő idegennel azonosítja, akit szent tisztelet lep meg, midőn megpillantja a mély elmélkedésbe és imába merült híveket. Eme látvány hatására elmélkedni kezd a vallás tárgyai, különböző megnyilvánulásai kapcsán, és e rövid eszmefuttatás keretében arra a következtetésre jut, hogy a katolikus vallás és a kvékerek vallása egymás ellentéteit képezik, mivel:

„Egyiket a meleg képzelödés, az ömledező sziv és morális genie alkotta volt, a másnak a bidegebb fontolgató ész és mély elmélkedés adott hitelt. Ezek között állnak kisebb és nagyobb eltérés és elegyitéssel a keresztény vallásnak több számtalan s mindég nevekedó felekezetei”. ${ }^{12}$

A különböző vallásokkal és a vallási sokféleséggel szembesülő utazó rendszeralkotói igyekezete és igénye nyilvánul meg abban, ahogy ezen felekezeteket egymáshoz viszonyítva meghatározza, illetve bizonyos szempont szerint (ebben az esetben: megnyilvánulásmód, szertartás, ima stb.) értelmezi. Kilép az objektív szemlélő szerepéből, amikor hangot ad a kvékerizmus, a kvékerek iránti rokonszenvének: e vallás antiklerikális volta számára egy ideális felekezetet testesít meg, amely az Istennel való személyes kapcsolatra épül, illetve lenyűgözi követőinek feddhetetlen jelleme és erkölcsileg példaadó élete. ${ }^{13}$

A csaknem személytelen jellegű útinapló a közvetlen élmények, tapasztalatok, benyomások tárhelyeként funkcionál, míg a nyilvánosság elé szánt útikönyv a szelekció és kombináció

lójában és útikönyvében címú előadás keretében. Ennélfogva e tanulmányban terjedelmi okok miatt nem kerülnek részletezésre ezen aspektusok

10 Bölöni Farkas Sándor Utazás Nyugat-Európában. Naplótöredék. Mentor, Marosvásárhely, 2008. 114-115. (BöLÖNi FARKAs 2008)

11 Magyar nagylexikon. Szerk. Glatz Ferenc. XV. Bp., Magyar Nagylexikon, 2002. 720.

12 BÖLÖNI FARKAS 2008. 231.

13 Vö.: BölöNi Farkas 2008. 231-232. 
síkján, utólagos szerkesztői tevékenység eredményeként jött létre. Az útikönyvben úgy jelennek meg a vallások, hogy reprezentációjuk által a különböző felekezetek egyenrangúságának eszméjét, a vallásos tolerancia gondolatát propagálja Bölöni Farkas, míg az útinapló személyes jellege nem követel „megszorításokat” és bizonyos vonatkozások elhallgatását. E tényből kiindulva megvizsgáltam, hogy milyen az útinapló amerikai részében megjelenő vallások, felekezetek reprezentációja (a shakereké és metodistáké). ${ }^{14}$

Az útinaplóban Bölöni Farkas beszámol egy olyan incidensről, ami a shakereknél történt, de elhallgatja ezen esetet az útikönyvben. Eszerint a shakerek rituális szertartása után az idegenek közül felszólalt egy kvéker, amelynek ez lett a következménye:

\section{„[...] 's akarta a vallások külömbségét megmutatni, de kiverették. Ez vagy a Charlatánság legnagyobb neme, vagy a religioi fanatizmus legfelsóbb bolondsá- ga. ${ }^{" 15}$}

Nemcsak hogy kimarad ezen eseménytörténet az útikönyvből, ám tartalma szerint ezen közlést/kijelentést is ambivalencia jellemez. A napló szövegkörnyezetéből sem derül ki, hogy kire - a kvékerre vagy a shakerekre - vonatkozik az elmarasztaló megjegyzés. Ugyanebben a bejegyzésében a metodisták kapcsán is a fanatizmust emlegeti a naplóíró Bölöni Farkas „ $A$ Vallásos fanatizmusnak ily bolondságait képzelni nem lehet"16, míg az útikönyvben nem használja ezen beszámolókban a fanatizmus szót, teljesen kiiktatja azt, átesztétizált élményként jelenítve meg az olvasó számára az amerikai shakerek és metodisták körében szerzett tapasztalatait. Úgy gondolom, hogy az Amerikai Egyesült Államokról kialakított csaknem idealisztikus demokráciaképet ${ }^{17}$ megtörné az, ha a vallási fanatizmus meglétét emlegetné a szabadság metaforájaként funkcionáló és reprezentált állam esetében. Ennélfogva a vallási fanatizmus és bigottság tartalma csupán az Óvilágra való utalás esetében jelenhet meg az útikönyvben:

„Európa akármelyik országában kettó is elég együtt [felekezet], bogy egymás
életét keserüvé tegyék”. ${ }^{18}$

Azon kutatások, amelyek az útikönyv vallással kapcsolatos narratíváit elemezték, egyöntetűen amellett érveltek, hogy az a tolerancia, a bölcs és békés megértés, ahogy az útleíró a kvékerekhez, shakerekhez vagy metodistákhoz viszonyul, annak tulajdonítható, hogy egy de-

14 A továbbiakban Bölöni Farkas útinaplójára - mely a kolozsvári Román Akadémiai Könyvtár (Biblioteca Academiei Române, Cluj-Napoca) kézirattárában található - annak jelzetszámával, MsU 959, hivatkozom.

$15 \mathrm{MsU} 959,123 \mathrm{v}$.

$16 \mathrm{MsU} 959,124 \mathrm{r}$.

17 Bölöni Farkas Sándor számára az Amerikai Egyesült Államok egy eszmei vágyképet testesít meg - a múködő demokráciáét -, a látottakat pedig egy eszmei-ideológiai keretbe helyezi. (lásd VÁRI István: Fenyegetések földje. Amerika a 19. század második felében-magyar szemmel. Korall XXVI(2006).153-155.

18 BölÖNI FAR KAs 1966. 218. 
mokrata és liberális utazó szemével tekint a különböző vallási megnyilvánulásokra, egy olyan utazóéval, aki a vallásos megkülönböztetés elől is az Amerikai Egyesült Államokban keres menedéket. ${ }^{19} \mathrm{~A}$ közelmúltban viszont fény derült arra - az útinapló különböző szöveghelyeinek és egyéb szövegek, paratextusok bevonása révén az értelmezési keretbe -, hogy Bölöni Farkas egyrészt tulajdonképpen az erdélyi unitárius egyház megbízottjaként, diplomatájaként indult külföldre az angliai és amerikai hitrokonokkal való kapcsolatfelvétel céljából. ${ }^{20}$ Ennek ellenére az útikönyvben csupán szúkszavúan utal az amerikai unitáriusokra - noha ismerteti azt, hogy miként terjedt el a vallás az Amerikai Egyesült Államokban, vagy ír arról, hogy a Harvardon tanító professzorok nagy része unitárius -, és nem említi azt, még nem is utal arra, hogy az erdélyi unitáriusok diplomatájaként érkezett Angliába, illetve az Amerikai Egyesült Államokba. A megjelent útikönyvvel ellentétben a személyes használatra szánt útinapló már számtalan olyan bejegyzést tartalmaz, amely korabeli egyház-diplomáciai tevékenységéről tanúskodik:

„Wood úr elvezett Hunter nevú könyvtároshoz, és ajánlott neki, azután az Unitarian Committee-be vezetett fel, s a secretárius úrnak ajánlott, ki több könyveket adott által az angliai unitáriusok bistóriájára”. ${ }^{21}$ (április 21.)

"Wood Samuel úr az unitarian Committee gyúlésébe vitt, egybegyúlvén a tagok, Yates úr propoziciót tett irántam, hogy Erdélyból, mint unitarian ide érkezvén, protocollariter gratuláltak nekem, s kijelentették, hogy általam kivánják fenntartani az erdélyi atyafiakkal való közösülést”. ${ }^{22}$ (április 25.),

„Délután Yates úr hozzám jött, s a Carter Lane, Doctors Common Unitarian Templomba vitt. Fox úr prédikált, az evangéliumból mutatta meg, hogy a Krisztus a maga eljövetelével reformot akart és tett, Luther hasonlólag. Reform kell a világnak, politikai és vallásos szabadság". ${ }^{23}$ (május 1.)

E tény és a vallás különböző megnyilvánulásaival, tárgyaival való andalgásai, illetve transzcendentális elmélkedései mind azt bizonyítják, hogy nem csupán egy demokrata és deista szabadgondolkodó hangján szólal meg, mint ahogy az 1930-as években feltételezték. A shakerek és metodisták különleges ceremóniája után utazónk így kiált fel:

„S ki merhet az isten és az ôk lelkiesméretek közé felállni itéletével!, ”majd így folytatja „Mindenható! Ezek közöl melyiknek imádsága foganatosabb elötted?". 24

19 Lásd Hatvany Lajos: Egy székely nemes, aki felfedezte a demokráciát = Uő: Öt évtized (tanulmányok, cikkek). Szépirodalmi, Bp., 1961. 442-448.

20 Lásd Kovács Sándor: Angolszász-magyar unitárius érintkezések a 19. században. Kvár, EME, 2011 (Erdélyi Tudományos Füzetek 269). 42-49.

21 BÖLÖNI FARKAS 2008. 161.

22 BÖLÖNI FARKAS 2008. 162.

23 BÖLÖNI FARKAS 2008. 165.

24 BöLÖNi FARKAS 1966. 122-124. 
Ahogy a Mindenhatóra bízza a leghathatósabb imák, illetve a Számára legkedvezőbb vallási forma kiválasztását, mind azt támasztják alá, hogy az unitáriusok szelídségével és toleranciájával viszonyul ezen vallásokhoz. Az unitáriusok örökségéhez kapcsolódik, hiszen az unitarizmus, az unitárius hit- és gondolatrendszer egyik központi eleme a vallásszabadság, a lelkiismereti szabadság tétele, amely nem csupán a vallási igazságok szabad és értelmes vizsgálatát jelenti, hanem egyben türelmes magatartásra indít mások vallásos meggyőződése és világnézeti felfogása iránt. ${ }^{25}$ Sőt a kolozsvári Unitárius Kollégium vallásos környezetében nevelkedett nyugat-európai és észak-amerikai utazó azt is hangsúlyozza, hogy az Istennel való személyes kapcsolat korlátlan és feltétlen szabadságának a megélése mindenki számára biztosított kell legyen, amelyet nem gátolhat semmilyen állami, egyházi forma vagy személy, tehát az unitáriusok hangján megszólaló utazó azt emeli ki, hogy a lelkiismereti meggyőződésnek nem szabhat határt semmilyen külsőség vagy külső tekintély:

\begin{abstract}
„És ki meri józan ésszel meghatározni, hogy melyiknek tisztelete kedvesebb, s kérelme foganatosabb az Isten elött? Ki az a por és hamu-nevezzék bár azt királynak, eklézsiának vagy státusnak -, ki az embernek lelke és az Isten közé meri magát béfúrni mint itélö biró?”. ${ }^{26}$
\end{abstract}

Az útikönyv eme és hasonló jellegű transzcendentális elmélkedései ékes bizonyítékaivá válnak annak, hogy unitárius utazóként türelmes magatartást tanúsít mások vallásos meggyőződése, világnézeti felfogása iránt, igyekszik pártatlanul szemlélni a vallások különböző megnyilvánulásait, miközben a vallásszabadság gondolatát hirdeti. Ám az útinapló egyes szöveghelyei arra is rámutatnak, hogy amellett, hogy noha türelmes mások világnézeti felfogása iránt, mégis Voltaire-hez hasonlóan a különböző vallási formák bemutatása, illetve azok vizsgálata közben, mint szabadgondolkodó elítéli a vallásos (és egyéb jellegű) fanatizmust, mivel a fanatizmusban olyan veszélyt lát, ami a józan ítélőképességet, és az Istennel való személyes kapcsolat megélését befolyásolja. Összegzésképpen, olvasatom szerint, Bölöni Farkas Sándor nemcsak úgy értelmezi a nyugati vallásokat, mint egy demokrata és liberális gondolkodó, hanem egyben az unitáriusok szemével, látásmódjával (toleranciájával) viszonyul a különböző felekezetekhez.

A tanulmány második fele azt vizsgálja, hogy más 19. századi unitárius utazó miként látja és értelmezi, tehát írásaiban reprezentálja a nyugat vallási sokszínűségét. E rövid kontrollvizsgálat keretében így arra a kérdésre keresem a választ, hogy Bölöni Farkas Sándor volt-e az egyetlen olyan utazó, akit ennyire foglalkoztatott a nyugat vallásos élete, és az unitáriusok szelídségével ily toleranciával, illetve békés és bölcs megértéssel viszonyult a különböző felekezetek hitvilágához.

Bölöni Farkas Sándor után több mint negyven évvel Derzsi Károly (1849-1905) 1872ben Londonba utazott abból kifolyólag, hogy a Manchester New College alumnusaként ta-

25 Rezi Elek: „Az Úr, a mi Istenünk, egy Úr” (Bevezetés az unitárius vallás és teológia világába). Kolozsvári Egyetemi Kiadó, Kvár, 2009. 79-81.

26 BölÖNI FARKAS 1966.301. 
nulmányokat folytasson. ${ }^{27}$ Mivel utazása intézményes keretek között folytatott tanulmányútként értelmezhető, ennélfogva - Kovács Sándor szóhasználatával élve - a 19. századi unitárius peregrinatio academica sorába illeszthető. Ám Londonban nemcsak teológiai előadásokat látogatott, klasszikus filológiát és összehasonlító nyelvészetet hallgatott, hanem csaknem kétéves londoni tartózkodása alatt egy olyan úti beszámolóhoz hasonló riportot írt, amely a Keresztény Magvető folyóirat hasábjain jelent meg 1874-ben: Londoni vallásos élet s felekezetek címmel. ${ }^{28}$

Derzsi Károly riportját egy helyzetképpel indítja, élénken szemlélteti azt, hogy vasárnap a fơváros lakói milyen vallásos igyekezettel és buzgalommal indulnak templomba:

„Egy vasárnap Anglia valamelyik városában, s még inkább a világ e metropolisában, Londonban, az adásvevés e leirhatatlan fészkében, nem remélt bizonyságot nyujt arról, hogy a tömeg, mely hat napon át a mindennapi élet tevékenység-harczát vívja, a keresztény szombatot [...] mély tiszteletében részesiti. ${ }^{29}$

Tartalmilag több hasonló szövegrészlet található Bölöni Farkas Sándor úti prózájában is, amelyekben az utazó az angolok és amerikaiak a vasárnap szentsége iránt tanúsított magatartása kapcsán értekezik. Ám Derzsi Károly utazóként és megfigyelőként receptív a londoni vallásos élet más vonatkozására is: az utcai prédikátorok jelenlétére figyel fel, akik a különböző tereken beszédeket tartanak és híveket toboroznak.

Beszámolójának második nagyobb egységében Anglia felekezeti megoszlásáról nyújt egy részletes áttekintést, miközben határozott állást foglal ezek kapcsán. Szisztematikusságra törekedve beilleszt egy táblázatot, amelyben két részre tagolódnak London akkori egyházai: az első oszlopban az államegyházak (konformistákat), míg a másodikban a nem államegyházak (dissenterek) kerülnek. Részletesen elemzi az anglikán püspöki egyházakat, és Voltaire-hez hasonlóan csaknem 150 év elteltével a „magas” egyházat kritizálja abból kifolyólag, hogy meglátása szerint az inkább a külsőségekhez (szertartáshoz) és a külső tekintélyhez (klérushoz) ragaszkodik. $^{30}$ Szimpátiáját egyértelműen a nonkonformistákkal szemben fejezi ki amiatt, hogy fó elvük a személyes hit és a személyesség (személyes kapcsolat Istennel):

„A bit mindenkinek személyes vagyona s nem articulusokban áll. Az istenneli közlekedés személyes jog, nem papi tetszetés; személyes szabadság, nem állami önkény". ${ }^{31}$

27 A Pallas nagy lexikona-Derzsi Károllyal kapcsolatos szócikk megtekinthető a MEK alábbi oldalán: http://www.mek.iif.hu/porta/szint/egyeb/lexikon/pallas/html/026/pc002628.html\#10 （utolsó megtekintés: 2013. szeptember 17.)

28 Derzsi Károly: Londoni vallásos élet sfelekezetek. Keresztény Magvető IX (1874). 221-236.

29 Derzsi 1874.221.

30 Derzsi 1874.227-228.

31 Derzsi 1874.231. 
Így ismerteti a különböző nonkonformista felekezeteket: az independensektől indul, majd említést tesz a baptistákról, presbiteriánusokról, unitáriusokról, metodistákról, kvékerekről, swedenborgiánusokról stb.

Noha először kritikával illeti a külsőségekhez, külső tekintélyhez, a sacerdotalizmushoz ragaszkodó magas anglikán egyházat, mégis fegyelemre és türelemre inti a kívülállót és önmagát:

„De ne alkalmazzunk erös kritikát a magas egyháziakra; habár templomaikba betérve gyakran hallunk is a józan ész s érzéssel ellenkezó tanokat hirdetve, mindezt elfeledteti, elfödi a megromlottnak hirdetett emberi természet tiszta, vallásos ömledezése. Sót még a ritualisták felett sem törhetünk pálcát". ${ }^{32}$

Tehát az unitáriusok szelídségével szemléli a különböző felekezeteket, teljesen lenyűgözik a nonkonformisták, mivel meglátása szerint az Istennel való személyes kapcsolatra alapozzák hitüket. Sőt beszámolójának első felében e liberális teológus eljátszadozik egy egyetemes egyház gondolatával is, ami szerinte csak akkor jöhet létre, ha mindenkinek először személyes vallása és hite lenne, tehát egy autonóm személyiség gondolatát hirdeti.

Összegzésként megállapítható, hogy mindkét utazó (kellő) alázatossággal és toleranciával szemléli a nyugat különböző, főként keresztény és ezen belül protestáns felekezeteit, amit egyöntetűen elítélnek, az a fanatizmus megnyilvánulása. Bölöni Farkas Sándor útikönyve nemcsak azt az üzenetet hordozza, hogy minden vallás egyenértékű, hiszen a könyv különböző transzcendentális elmélkedései, illetve Monroe elnök beszéde ${ }^{33}$ által a személyes hit, a lelkiismereti meggyőződés szabadságának a gondolatát is propagálja. Derzsi Károly már sokkal radikálisabb gondolkodó, mint elődje, nemcsak pozitív fényben mutatja be London nonkonformista felekezeteit, hanem már egy egyetemes vallás gondolatával is foglalkozik.

Ugyanakkor közös vonás mindkét utazó esetében az, hogy igyekeznek magyarázatot találni a nyugat vallásos diverzitására. Ám míg Bölöni Farkas Sándor azt a konstitúcióból fakadónak látja, mivel meglátása szerint az Amerikai Egyesült Államokban az alkotmány biztosítja a vallások szabad gyakorlásának lehetőségét, addig Derzsi egy teljesen más magyarázatot fogad el a kor elismert teológusa hatására, és ennélfogva Ignaz von Döllinger elméletét építi be a riport gondolatmenetébe. ${ }^{34}$

32 Derzsi 1874. 228.

33 Bölöni Farkas Sándor útikönyvének XVIII. fejezetében idézi Monroe elnök a Kongresszushoz intézett beszédét: „Tagadhatatlan igazság, hogy vallásunk s külső jelek által gyakorlott isteni tiszteletünket csak elménk s meggyózödésünk s nem kénszerités által határozhatni meg. Minden embernek jussa van lelkiesmérete meggyözödése szerinti vallást követni. Ezen juss a természettól adatott s elidegenithetetlen". (BölöNi FARKAS 1966. 221)

34 Tartalmi, illetve terjedelmi kötöttségek miatt a tanulmány nem foglalkozik Ignaz von Döllinger elméletének az adaptációjával. 


\section{THE REPRESENTATION OF (WESTERN) RELIGIONS IN THE TRAVEL WRITINGS OF TRANSYLVANIAN (UNITARIAN) TRAVELLERS}

\section{Keywords: traveller, Unitarian, $19^{\text {th }}$ century, religious diversity, Voltaire, tolerance, freedom of conscience}

The aim of this study is to explore the theme of religions/religious diversity in the travel writings of two Unitarian travellers, namely Alexander Bölöni Farkas and Charles Derzsi. Since one key-element of Unitarian theology is religious tolerance insisting on the idea of freedom of conscience - according to which each individual in his views is given the same free as Adam and Eve -, it is particularly interesting to examine how these two travellers coming from Transylvania represented and interpreted in the $19^{\text {th }}$ century the different and newly emerged denominations of the 'West'.

The study begins with a(n literary) outlook, interpreting some essays of Voltaire's Letters on the English (1733) in which the French philosopher describing the Quakers, Presbyterians, Anti-Trinitarians analysed England's religious life. Then a special emphasis is given to highlight how Alexander Bölöni Farkas, as an accredited diplomat of the Transylvanian Unitarian Church, implicitly criticized the religious intolerance of his homeland through representing and interpreting in his travel writings (Journey in North America, travel journal) the legal status of the religions in the USA and the unusual religious practices - the divine service, the doctrine, the life-style, the distinctive clothing - of the Quakers, Shakers, Methodists. Finally, as a control study Charles Derzsi's report is drawn into analysis (Religious Life in London and Denominations) in which the Unitarian alumnus systematically summarized the different denominations of the capital, as he propagated the idea of religious tolerance and personal faith.

\section{REPREZENTAREA RELIGIILOR (DIN OCCIDENT) ÎN TEXTELE CĂLĂTORILOR ARDELENI (ŞI UNITARIENI) DIN SECOLUL AL XIX-LEA}

\section{Cuvinte-cheie: călător, unitarian, secolul al XIX-lea, diversitate religioasă, Voltaire, toleranţă, libertatea de conştiinţă}

Scopul acestui studiu este de a explora diversitatea religioasă din textele ale călătorilor ardeleni, Sándor Bölöni Farkas și Károly Derzsi. Întrucât elementul-cheie a teologiei unitariene este toleranţă religioasă accentuând libertatea de conștiinţă, este deosebit de interesant de a examina cum au reprezentat și cum au interpretat cei doi călători din Ardeal în secolul al XIX-lea confesiunile diferite și recent apărute în Vest.

Studiul începe cu interpretarea a unor eseuri din Lettres anglaises (1733) în care Voltaire, filozoful francez, a analizat în detaliu viaţa religioasă a englezilor prin descrierea Quakerilor, Presbiterianilor și Anti-trinitarienilor. După această analiză un accent deosebit este pus pe evidenţierea modului prin care Sándor Bölöni Farkas, ca diplomatul acreditat a Bisericii Unitariene din Transilvania, a criticat intoleranţa religioasă existând în ţara sa natală prin reprezentarea și interpretarea statutul legal a religiilor din SUA și practicile religioase neobișnuite - serviciul divin, doctrina, stilul de viaţă, îmbrăcămintea distinctivă - a Quakerilor, Shakerilor și Metodiștilor. În cele din urmă, ca un studiu de caz control raportul lui Károly Derzsi este analizat în detaliu în care absolventul/bursierul Unitarian a rezumat sistematic diferite confesiuni din capitala Marii Britanii, în timp ce a propagat idei ca toleranţă religioasă și credință personală. 